\title{
КЛАСТЕРНИЙ АНАЛІЗ ВІЙСЬКОВО-МЕДИЧНИХ КЛІНІЧНИХ ЦЕНТРІВ ТА ВІЙСЬКОВИХ ГОСПІТАЛІВ ЗБРОЙНИХ СИЛ УКРАЇНИ ЗА ПОКАЗНИКАМИ ВИКОРИСТАННЯ ЛІЖКОВОГО ФОНДУ У 2010 РОЦІ
}

€. Б. Лопін

\author{
Науково-дослідний інститут проблем військової медицини Збройних Сил України
}

\begin{abstract}
В статті на основі даних галузевих щорічних медичних звітів за формою 3/Мед за допомогою кластерного аналізу, здійсненого за методом k-середніх, проаналізовані показники використання розгорнутих ліжок військово-медичних клінічних центрів та військових госпіталів за 2010 рік. Проведена порівняльна оцінка використаного методу статистичного аналізу з іншим методом оцінки показників використання ліжкового фонду. 3 метою підвищення ефективності використання розгорнутих ліжок дані рекомендації керівництву закладів охорони здоров'я та органам управління медичної служби Збройних Сил України.
\end{abstract}

Ключові слова: військово-медичні клінічні центри, військові госпіталі, показники використання розгорнутих ліжок, кластерний аналіз лікувальних закладів за методом k-середніх.

\section{КЛАСТЕРНЫЙ АНАЛИЗ ВОЕННО-МЕДИЦИНСКИХ КЛИНИЧЕСКИХ ЦЕНТРОВ И ВОЕННЫХ ГОСПИТАЛЕЙ ВООРУЖЁННЫХ СИЛ УКРАИНЫ НА ОСНОВЕ ПОКАЗАТЕЛЕЙ ИСПОЛЬЗОВАНИЯ КОЕЧНОГО ФОНДА В 2010 ГОДУ}

Е. Б. Лопин

\author{
Научно-исследовательский институт проблем военной медицины \\ Вооружённых Сил Украины
}

\begin{abstract}
В статье на основании данных ведомственных ежегодных отчётов по форме 3/Мед с помощью кластерного анализа, проведенного методом k-средних, проанализированы показатели использования коечного фонда военно-медицинских клинических центров и военных госпиталей за 2010 год. Проведена сравнительная оценка использованного метода статистического анализа с другим методом оценки показателей использования коечного фонда. Даны рекомендации руководству учреждений здравоохранения, а так же органам управления медицинской службы Вооружённых Сил Украины относительно более эффективного использования коечного фонда.
\end{abstract}

Ключевые слова: военно-медицинские клинические центры, военные госпитали, показатели использования развёрнутых коек, кластерный анализ лечебных учреждений по методу k-средних.

\section{CLUSTER ANALYSIS OF MILITARY-MEDICAL CLINICAL CENTERS AND MILITARY HOSPITALS OF THE ARMED FORCES OF UKRAINE BASED ON INDICES OF HOSPITAL BEDS IN 2010}

Military Medicine Research Institute of Armed Forces of Ukraine

Based on analysis of annual 3/Med medical reports using k-means clustering method, indices of deployed hospital beds of military-medical clinical centers and military hospitals have been analyzed. A comparative evaluation of the selected statistical analysis method and the other method, used for this research, have been performed. Recommendations managers of health 
facilities as well as the management authorities of the Medical Service of the Armed Forces of Ukraine on more efficient use of deployed beds have been given.

Key words: military-medical clinical centers, military hospitals, indices of deployed hospital beds, k-means cluster analysis of hospitals.

Вступ. Забезпечення ефективного використання ліжкового фонду лікувальних закладів охорони здоров'я внаслідок високої вартості його утримання $[1,2,3]$ було і залишається одним з найактуальніших питань управління охороною здоров'я. Відповідно в органах управління та наукових підрозділах медичної служби Збройних Сил України в рамках запроваджених [4] моніторингових досліджень на основі даних галузевої відомчої статистичної звітності здійснюється щорічний аналіз результатів діяльності закладів охорони здоров'я, у тому числі показників використання розгорнутих та штатних ліжок. Повноцінно та якісно вирішити це завдання неможливо без застосування технологій та методик математичного статистичного аналізу, підкріплених відповідним програмним забезпеченням.

В попередніх дослідженнях нами вже була здійснена спроба проаналізувати показники використання ліжкового фонду лікувальних закладів охорони здоров'я Збройних Сил України [5] за допомогою методик багатомірного статистичного аналізу, однак отримані в рамках даних досліджень результати на наш погляд недостатньо повні, потребують систематизації та подальшого ретельного вивчення. Це, а також те, що в найбільш грунтовних та змістовних публікаціях з даного напрямку [6, 7] застосування нових технологій статистичного аналізу показників використання ліжок лікувальних закладів охорони здоров'я практично не було відображене, і обумовило актуальність та практичну цінність даного дослідження.

Метою дослідження було визначення практичної придатності, показовості, точності та адекватності такого нетрадиційного методу аналізу показників використання ліжкового фонду закладів охорони здоров'я, як кластерний аналіз за методом к-середніх, а також визначення лікувальних закладів охорони здоров'я Збройних Сил України (військово-медичних клінічних центрів та військових госпіталів), що потребують здійснення корекції (покращення) показників використання розгорнутих ліжок.

Матеріали та методи досліджень. В якості вихідних даних у дослідженні використовувались абсолютні значення показників руху хворих військових лікувальних закладів охорони здоров'я Збройних Сил
України за 2010 р., отримані з медичних звітів за формою 3/Мед, зміст, терміни та порядок складання яких встановлені директивою Начальника Генерального штабу Збройних Сил України $\mathrm{N}^{\circ}$ ДГШ-11 від 17 грудня 2001 року [8].

На основі даних показників (кількість хворих, що надійшли до та виписались/вибули з лікувальних закладів протягом року, кількість хворих, що знаходились на лікуванні на початок та наприкінці річного звітного періоду, кількість проведених хворими ліжкоднів) були розраховані за прийнятою у Збройних Силах методикою [9] показники, що характеризують використання розгорнутих ліжок лікувальних закладів $^{1}$ - використання фактичної ліжкової потужності, оберт розгорнутого ліжка, середній термін перебування хворих на ліжку. 3 вибірки були усунені два заклади - 9 (м. Десна) та 412 (м. Новоград-Волинський) військові госпіталі, для яких показник використання фактичної ліжкової потужності відповідно склав $102,86 \%$ та 99,70 \% (134,44 \% для хірургічних відділень). Також сумнівними були звітні дані за 407 (м. Чернігів) військовий госпіталь, де кількість виписаних хворих (3001 чол.) була однаковою для хірургічних та терапевтичних відділень, але даний госпіталь був залишений серед об'єктів, що досліджувались.

Для статистичного аналізу розрахованих показників був використаний відомий в аналітичній статистиці метод кластерного аналізу за методом k-середніх (англ. - k-means) [10]. Використані для здійснення кластерного аналізу показники використання ліжкового фонду представлялися в шкалі від 0 до 1 шляхом нормування до максимального значення показника в групі [11].

Нормування показників здійснювалось наступним чином:

$$
\begin{aligned}
& d_{i]}=\frac{X_{\mathrm{X}^{1}}^{\text {norm }}}{{ }_{\text {т а }}}{ }_{{ }_{i j}-{\frac{X_{\text {norm }}^{i}}{x i}}_{\text {norm }}-X_{i j}}
\end{aligned}
$$

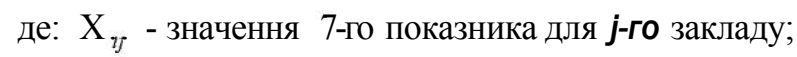


$\mathrm{X}_{\text {nогт }}{ }_{\text {nот }}$ - нормувальне значення 7-го показника (визначається на основі максимального у групі або максимально можливого значення показника).

ё/ - нормований 7-й показник для 7-го закладу, $0 \leq \ddot{\mathrm{e}}_{7}<1 \quad$ :

При цьому, формула (1) використовується, якщо показник оцінюється за принципом "більше - краще", формула (2) - за принципом " менше - краще".

Окрім цього, для кожного закладу (/-го об'єкта) на основі розрахованих нормованих показників визначався інтегральний показник I:

$$
I_{j}=100 \times \frac{\sum_{i=1}^{n} d_{i j}}{3}
$$

де: 3 - максимальна сума нормованих показників. Наведене у формулі (3) представлення інтегрального показника доцільне, коли приймається гіпотеза про рівнозначність кожного використано- го у дослідженні показника використання ліжкового фонду.

Додатково для оцінки кореляційних зв'язків показників також за прийнятими методиками визначались коефіцієнти кореляції Браве-Пірсона (r) та Спірмена $\left(\mathrm{r}_{\mathrm{s}}\right)$, а також необхідний для їх оцінки t-критерій [12].

Математичні розрахунки проводились за допомогою власноруч розробленої в середовищі програмування Delphi комп'ютерної програми ' Stat", програми Microsoft Excel з пакета Microsoft Office та такої відомої статистичної програми, як STATISTICA (version 6, StatSoft, Inc.).

Результати досліджень та їх обговорення. Перед проведенням аналізу показників за допомогою кластерного аналізу нами була здійснена оцінка показників, що характеризують використання розгорнутого ліжкового фонду військово-медичних клінічних центрів (далі ВМКЦ) та військових госпіталів (далі ВГ) Збройних Сил України на наявність кореляційних зв'язків. Коефіцієнти кореляції Браве-Пірсона (r) та кореляції рангів Спірмена (r) розраховані $з$ цією метою, наведені в таблиці 1.

Таблиця 1. Значення коефіцієнта кореляції для експериментальних рядів показників використання розгорнутих ліжок військово-медичних клінічних центрів і військових госпіталів за 2010 рік

\begin{tabular}{|l|c|c|c|c|c|c|c|c|}
\hline \multicolumn{1}{|c|}{$\begin{array}{c}\text { Показники } \\
\text { використання } \\
\text { ліжкового фонду }\end{array}$} & $\begin{array}{c}\text { Викор. факт. } \\
\text { ліжк. } \\
\text { потужн. }\end{array}$ & $\begin{array}{c}\text { Сер. трив. } \\
\text { переб. хв. на } \\
\text { ліжку }\end{array}$ & $\begin{array}{c}\text { Оберт } \\
\text { розг. ліжка }\end{array}$ & $\begin{array}{c}\text { Викор. } \\
\text { факт. ліжк. } \\
\text { потужн. }\end{array}$ & $\begin{array}{c}\text { Сер. трив. } \\
\text { переб. хв. } \\
\text { на ліжку }\end{array}$ & $\begin{array}{c}\text { Оберт } \\
\text { розг. ліжка }\end{array}$ \\
\hline $\begin{array}{l}\text { Викор. факт. } \\
\text { ліжк. потужн. }\end{array}$ & $r$ & & 0,05 & 0,68 & $r_{S}$ & & $-0,005$ & 0,63 \\
\cline { 2 - 10 } & $|t|$ & & 0,23 & 4,13 & $|t|$ & & 0,02 & 3,66 \\
\hline \multirow{2}{*}{$\begin{array}{l}\text { Сер. трив. переб. } \\
\text { хв. на ліжку }\end{array}$} & $r$ & 0,05 & & $-0,69$ & $r_{S}$ & $-0,005$ & & $-0,73$ \\
\cline { 2 - 10 } & $|t|$ & 0,23 & & 4,28 & $|t|$ & 0,02 & & 4,78 \\
\hline \multirow{2}{*}{ Оберт розг. ліжка } & $r$ & 0,68 & $-0,69$ & & $r_{S}$ & 0,63 & $-0,73$ & \\
\cline { 2 - 10 } & $|t|$ & 4,13 & 4,28 & & $|t|$ & 3,66 & 4,78 & \\
\hline
\end{tabular}

* Примітка: для кількості ступенів свободи: $t_{0,1}=1,725 ; t_{0,05}=2,086 ; t_{0,01}=2,845 ; t_{0,001}=3,850$.

На наш погляд, наявність визначених достовірних кореляційних зв'язків між окремими показниками не $\epsilon$ перешкодою для застосування такого методу статистичного аналізу, як кластерний аналіз, здійснений за методом к-середніх, про що ще буде згадано наприкінці статті. За допомогою даного методу усі госпіталі та військово-медичні клінічні центри були поділені за показниками використання розгорнутих ліжок (використання фактичної ліжкової потужності, оберт розгорнутого ліжка, середній термін перебування хворих на ліжку) на 4 кластери. Графіки середніх для отриманих кластерів зображені на рисунку 1 , описова статистика отриманих кластерів наведена в таблиці 2.
Розподіл військово-медичних клінічних центрів та військових госпіталів за чотирма описаними в таблиці 2 кластерами наведений в таблиці 3. Окрім цього, в стовпчиках 3 та 4 таблиці 3 наведені інтегральний показник кожного лікувального закладу, розрахований за переліченими вище показниками використання ліжок, та відповідне рангове місце, які вже дозволяють здійснити інтегральну оцінку закладу.

Трактувати отримані результати можна виходячи $з$ того, що оцінка показників використання фактичної ліжкової потужності та оберту ліжка здійснюється за принципом "більше - краще", а показника середнього терміну перебування хворих 
Puc. 1. Графіки середніх для кластерів, визначених шляхом аналізу показників роботи розгорнутих ліжок військовомедичних клінічних центрів та військових госпіталів у 2010 році.

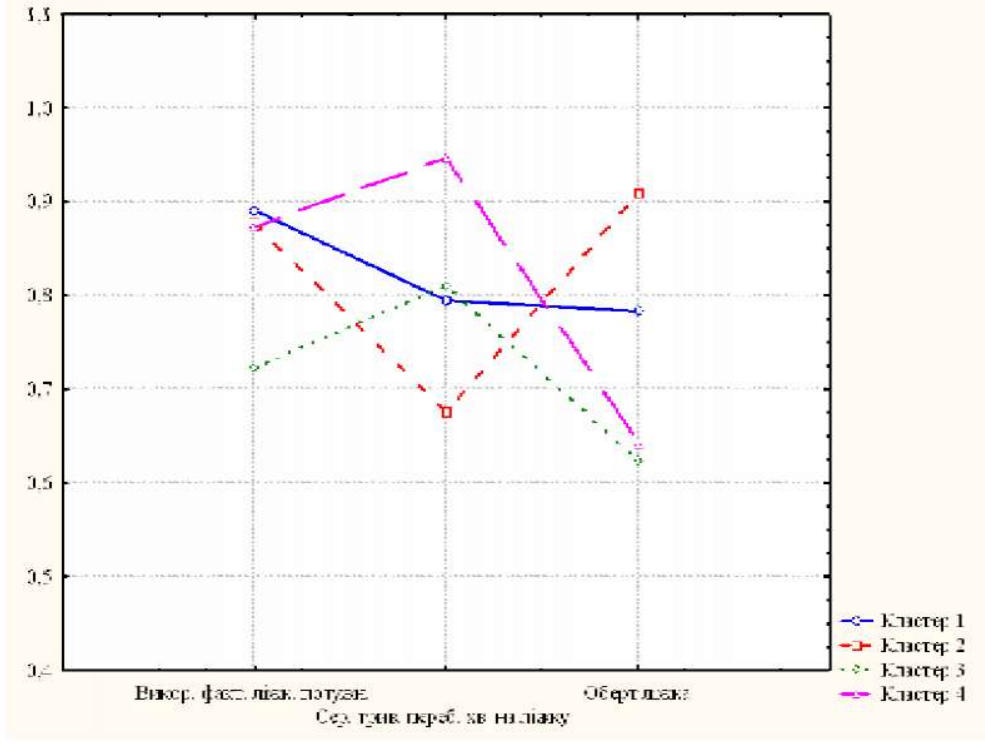

Таблиця 2. Описова статистика кластерів, визначених за показниками роботи розгорнутих ліжок військово-медичних клінічних центрів та військових госпіталів у 2010 році

\begin{tabular}{|c|c|c|c|c|}
\hline \multicolumn{2}{|r|}{ Показники кластерів } & \multirow{2}{*}{$\begin{array}{c}\text { Середнє } \\
0,89\end{array}$} & \multirow{2}{*}{$\begin{array}{c}\text { Стандартне (середнє } \\
\text { квадратичне) } \\
\text { відхилення }\end{array}$} & \multirow{2}{*}{$\begin{array}{c}\text { Дисперсія } \\
0,003 \\
\end{array}$} \\
\hline \multirow{3}{*}{$\begin{array}{c}\text { Кластер } \\
\text { №1 }\end{array}$} & Викор. факт. ліжк. потужн. & & & \\
\hline & Сер. трив. переб. хв. на ліжку & 0,79 & 0,04 & 0,002 \\
\hline & Оберт розг. ліжка & 0,78 & 0,04 & 0,001 \\
\hline \multirow{3}{*}{$\begin{array}{c}\text { Кластер } \\
\text { №2 }\end{array}$} & Викор. факт. ліжк. потужн. & 0,88 & 0,08 & 0,006 \\
\hline & Сер. трив. переб. хв. на ліжку & 0,67 & 0,03 & 0,0007 \\
\hline & Оберт розг. ліжка & 0,91 & 0,07 & 0,005 \\
\hline \multirow{3}{*}{$\begin{array}{c}\text { Кластер } \\
\text { №3 }\end{array}$} & Викор. факт. ліжк. потужн. & 0,72 & 0,05 & 0,003 \\
\hline & Сер. трив. переб. хв. на ліжку & 0,81 & 0,05 & 0,002 \\
\hline & Оберт розг. ліжка & 0,62 & 0,06 & 0,004 \\
\hline \multirow{3}{*}{$\begin{array}{c}\text { Кластер } \\
\text { №4 }\end{array}$} & Викор. факт. ліжк. потужн. & 0,87 & 0,10 & 0,010 \\
\hline & Сер. трив. переб. хв. на ліжку & 0,95 & 0,05 & 0,002 \\
\hline & Оберт розг. ліжка & 0,64 & 0,04 & 0,002 \\
\hline
\end{tabular}

Таблиця 3. Розподіл військово-медичних клінічних центрів та військових госпіталів за кластерами, визначеними на основі показників роботи розгорнутих ліжок у 2010 році, та їх інтегральні показники

\begin{tabular}{|c|c|c|c|c|}
\hline Кластер & Військові госпіталі & $\begin{array}{c}\text { Інтегральний } \\
\text { показник }\end{array}$ & $\begin{array}{c}\text { Рангове місце за } \\
\text { інтегральним } \\
\text { показником } \\
\end{array}$ & $\begin{array}{c}\text { Середні відстані } \\
\text { від центрів } \\
\left.\text { кластерів (х } 10^{3}\right)\end{array}$ \\
\hline \multirow[t]{4}{*}{ Кластер №2 } & 762 ВГ, м. Біла Церква & 76,32 & 1 & 70,81 \\
\hline & 10 ВГ, м. Хмельницький & 71,01 & 2 & 33,56 \\
\hline & 1467 ВГ, м. Миколаїв & 68,99 & 3 & 38,32 \\
\hline & 407 ВГ, м. Чернігів & 65,21 & 5 & 62,18 \\
\hline \multirow[t]{10}{*}{ Кластер №1 } & 1397 ВГ, м. Мукачеве & 67,93 & 4 & 76,44 \\
\hline & 376 ВГ, м. Чернівці & 65,09 & 6 & 25,65 \\
\hline & Головний ВМКЦ, м. Київ & 63,93 & 7 & 26,63 \\
\hline & ВМКЦ проф. пат., м. Ірпінь & 63,67 & 8 & 10,61 \\
\hline & 387 ВГ, м. Полтава & 62,45 & 9 & 17,27 \\
\hline & ВМКЦ Півд. регіону & 61,62 & 10 & 59,19 \\
\hline & ВМКЦ Захід. регіону & 61,33 & 11 & 19,54 \\
\hline & 409 ВГ, м. Житомир & 61,27 & 12 & 49,16 \\
\hline & ВМКЦ Центр. регіону & 59,87 & 13 & 41,60 \\
\hline & в/ч А-1615, смт. Черкаське & 59,40 & 14 & 36,57 \\
\hline
\end{tabular}


Продовження табл. 3

\begin{tabular}{|c|l|c|c|c|}
\hline \multirow{3}{*}{ Кластер } & \multicolumn{1}{|c|}{ Військові госпіталі } & $\begin{array}{c}\text { Інтегральний } \\
\text { показник }\end{array}$ & $\begin{array}{c}\text { Рангове місце за } \\
\text { інтегральним } \\
\text { показником }\end{array}$ & $\begin{array}{c}\text { Середні відстані } \\
\text { від центрів } \\
\text { кластерів (х 10 })\end{array}$ \\
\hline \multirow{3}{*}{ Кластер №4 } & 385 ВГ, м. Дніпропетровськ & 55,99 & 15 & 79,44 \\
\cline { 2 - 5 } & ВМКЦ Півн. регіону & 50,55 & 19 & 42,75 \\
\cline { 2 - 5 } & 386 ВГ, м. Сімферополь & 50,29 & 20 & 36,92 \\
\hline \multirow{3}{*}{ Кластер №3 } & ВМКЦ Кримського регіону & 55,03 & 16 & 39,38 \\
\cline { 2 - 5 } & 498 ВГ, м. Луцьк & 54,85 & 17 & 54,59 \\
\cline { 2 - 5 } & 450 ВГ, м. Запоріжжя & 54,11 & 18 & 45,81 \\
\cline { 2 - 5 } & 1445 ВГ, м. Староконстантинів & 46,18 & 21 & 51,67 \\
\cline { 2 - 5 } & 1129 ВГ, м. Рівне & 45,86 & 22 & 54,95 \\
\hline
\end{tabular}

на ліжку "менше - краще" [13, 14]. Відповідно до даного принципу здійснювати якісну оцінку кожного лікувального закладу можна шляхом визначен- ня належності до одного з типових кластерів, приклади графіків середніх для яких наведені в таблиці 4 [5].

Таблиця 4. Типові графіки середніх для кластерів, до яких були віднесені військово-медичні клінічні центри та військові госпіталі за показниками використання розгорнутих ліжок у 2008, 2009 та 2010 рр.

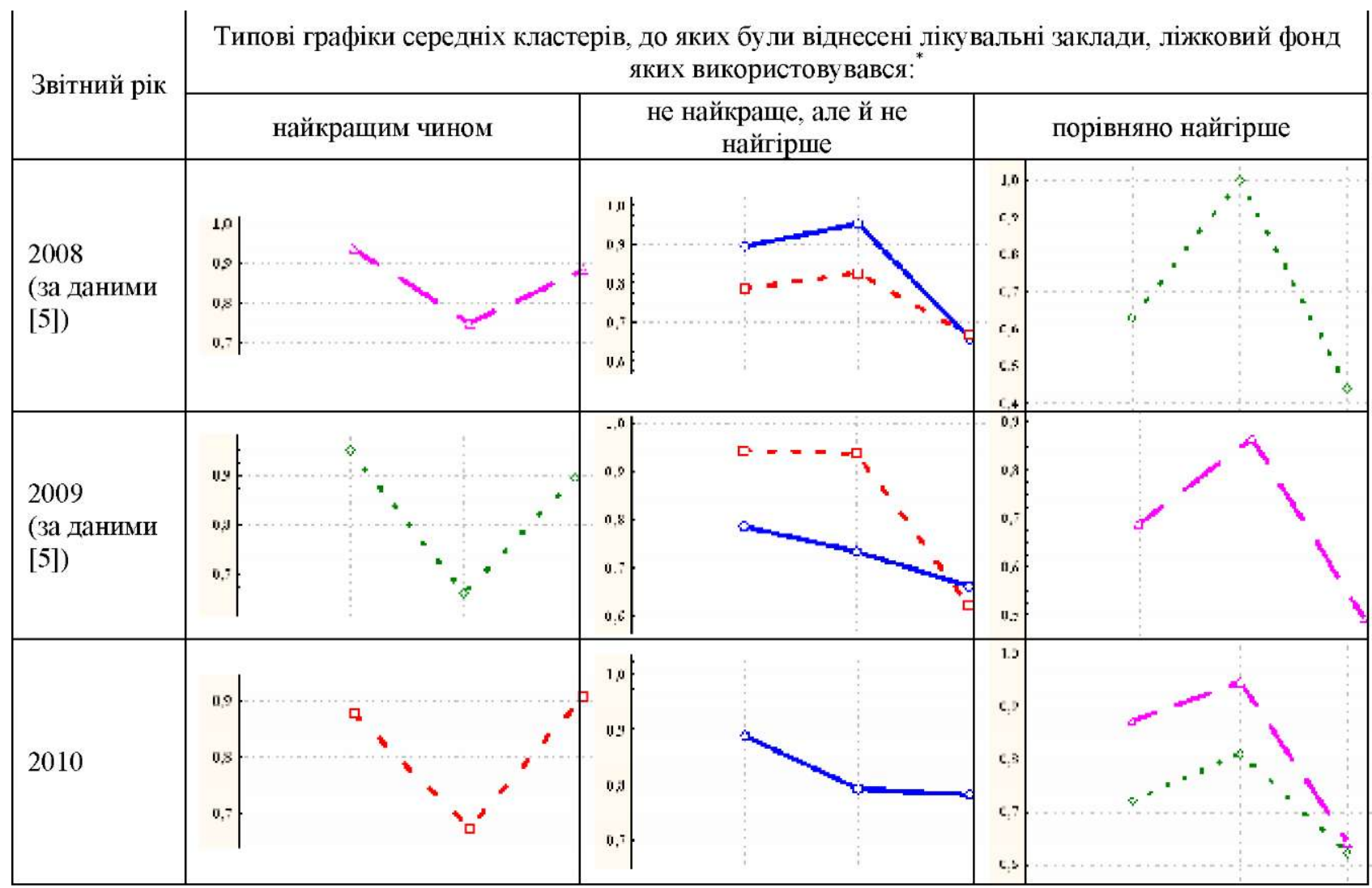

* Примітка: наведені в таблиці графіки середніх побудовані ідентично графікам, зображеним на рисунку 1, тобто використані ті ж самі показники та у тому самому порядку.

Тому можна констатувати, що до кластера № 2 (стовпчик 2 в таблиці 4, рядок за 2010 рік) були віднесені військові госпіталі, що характеризуються порівняно великим показником використання фактичної ліжкової потужності (82,35 \% в середньому за клас- тер $\left.^{1}\right)$, найбільшим показником оберту ліжка $(32,78)$, а також найменшим показником тривалості перебування хворого на ліжку (9,17 дня).

До кластерів № 3 та № 4 (стовпчик 4 в табл. 4, рядок за 2010 рік) були віднесені госпіталі, що мали

'Тут і далі при описі кластерів використовуються усереднені за кластер показники. 
найгірші у сукупності показники. Середні показники для даних кластерів склали: використання фактичної ліжкової потужності - 81,80 \% та 67,73 \%, оберт ліжка - 23,18 та 22,54, середня тривалість перебування хворого на ліжку - 12,85 та 11,01 дня. Відмінність кластеpa № 4 від кластера № 3 полягала у тому, що середній показник використання фактичної ліжкової потужності закладів даного кластера $(81,80 \%)$ був більшим за аналогічний показник кластера № 3 (67,73\%) переважно за рахунок збільшеного на 1,84 дня середнього терміну перебування хворого на ліжку.

Середні показники кластера № 1 (стовпчик 3 в таблиці 4, рядок за 2010 рік) свідчать, що у віднесених до нього лікувальних закладах найбільший серед кластерів показник використання фактичної ліжкової потужності (83,54 \%), але ще є значний резерв до покращення оберту ліжка $(28,27)$ та зменшення середньої тривалості перебування хворого на ліжку (10,79 дня).

Якісна оцінка використання ліжкового фонду військово-медичних клінічних центрів та військових госпіталів Збройних Сил України, проведена за допомогою кластерного аналізу за методом к-середніх, практично збіглася із результатами інтегральної оцінки даних закладів, здійсненої за допомогою розрахованого інтегрального показника (див. табл. 3). Як бачимо, згідно 3 даними таблиці 3, до кластерів № 3 та № 4 були віднесені лікувальні заклади, що зайняли 15-22 рангові місця. До кластера № 2 були віднесені заклади, що зайняли за інтегральним показником 1-3 та 5 місця, але вважаючи велику відстань від центрів кластерів
407 (м. Чернігів) та 1397 (м. Мукачеве) військових госпіталів, останній з яких зайняв 4 рангове місце, дану розбіжність можна вважати несуттєвою.

В цілому за допомогою кластерного аналізу за методом к-середніх військові лікувальні заклади було поділено на групи, якісна характеристика яких більш широка, ніж визначена за допомогою інтегрального показника, за яким було визначене лише рангове місце. Так, графіки середніх дозволяють оцінити одразу 3 показники в комплексі з врахуванням їх взаємозв'язку. Окрім цього, є можливість визначення додаткових якісних характеристик, що характеризують особливості управління ліжковим фондом. Так, згідно 3 даними таблиці 4 (стовпчики 3 та 4), в окремі кластери були згруповані заклади, в яких підвищення показника використання фактичної ліжкової потужності могло здійснюватись шляхом штучного збільшення середнього терміну перебування хворого на ліжку. В той же час в закладах з найбільшим показником оберту ліжка та найменшим середнім терміном перебування хворих на ліжку (стовпчик 2 табл. 4) високі значення показника використання фактичної ліжкової потужності були обумовлені більш інтенсивним використанням ліжок, тобто за рахунок збільшення кількості госпіталізованих та пролікованих за звітний період пацієнтів.

Також виявилось цікавим, що після групування госпіталів у кластери суттєво змінився характер кореляційних зв'язків між окремими показниками (табл. 5).

Таблиця 5. Значення коефіцієнта кореляції (Браве-Пірсона) для показників використання розгорнутих ліжок лікувальних закладів охорони здоров'я Збройних Сил України за 2010 рік, віднесених до різних кластерів

\begin{tabular}{|c|c|c|c|c|c|c|c|c|c|c|c|c|}
\hline \multirow{2}{*}{$\begin{array}{c}\text { № } \\
\text { показника }\end{array}$} & \multicolumn{3}{|c|}{ Кластер № 2} & \multicolumn{3}{|c|}{ Кластер № 1} & \multicolumn{3}{|c|}{ Кластер № 4} & \multicolumn{3}{|c|}{ Кластер № 3} \\
\hline & $1 *$ & 2 & 3 & 1 & 2 & 3 & 1 & 2 & 3 & 1 & 2 & 3 \\
\hline \multirow[t]{2}{*}{1} & & 0,44 & 0,89 & & 0,64 & 0,62 & & 1,00 & 1,00 & & $-0,20$ & 0,81 \\
\hline & & $p=0,56$ & $\mathrm{p}=0,11$ & & $\mathrm{p}=0,05$ & $\mathrm{p}=0,06$ & & $\mathrm{p}=0,06$ & $\mathrm{p}=0,04$ & & $\mathrm{p}=0,75$ & $\mathrm{p}=0,10$ \\
\hline \multirow[t]{2}{*}{2} & 0,44 & & $-0,009$ & 0,64 & & $-0,21$ & 1,00 & & 0,99 & $-0,20$ & & $-0,74$ \\
\hline & $\mathrm{p}=0,56$ & & $\mathrm{p}=0,99$ & $\mathrm{p}=0,05$ & & $\mathrm{p}=0,57$ & $\mathrm{p}=0,06$ & & $\mathrm{p}=0,10$ & $\mathrm{p}=0,75$ & & $\mathrm{p}=0,16$ \\
\hline \multirow[t]{2}{*}{ 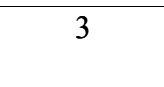 } & 0,89 & $-0,009$ & & 0,62 & $-0,21$ & & 1,00 & 0,99 & & 0,81 & $-0,74$ & \\
\hline & $\mathrm{p}=0,11$ & $p=0,99$ & & $\mathrm{p}=0,06$ & $\mathrm{p}=0,57$ & & $\mathrm{p}=0,04$ & $\mathrm{p}=0,10$ & & $\mathrm{p}=0,10$ & $\mathrm{p}=0,16$ & \\
\hline
\end{tabular}

* Примітка: тут і далі цифрою 1 позначений показник використання фрактичної ліжкової потужності, цифрою 2 середній термін перебування хворого на ліжку, цифрою 3 - оберт розгорнутого ліжка.

Наведені в таблиці 1 значення коефіцієнтів кореляції, а також дані таблиці 5 наводять на думку, що саме певний зв'язок між використаними в дослідженні показниками використання розгорнутих ліжок обумовлює групування досліджуваних об'єктів (військовомедичних клінічних центрів та військових госпіталів) до типових кластерів, графіки середніх для яких наведені в таблиці 4.
Наприкінці необхідно констатувати, що ліжковий фонд деяких військових госпіталів та військово-медичних клінічних центрів Збройних Сил України, особливо віднесених до кластерів № 4 та № 3, використовувався не найкращим чином. Іноді в силу причин, що не залежать від їх керівництва, а іноді внаслідок недостатньої уваги даному питанню. Також така картина частково може бути обумовлена відсутністю розроб- 
лених або адаптованих математичних методик аналізу, частково - відсутністю спеціального математичнопрограмного інструментарію. Саме його розробці в подальшому і будуть присвячені наші дослідження.

Висновки. 1. Наведені результати досліджень свідчать про показовість, адекватність і достатню точність запропонованої технології аналізу показників використання розгорнутого ліжкового фонду військових лікувальних закладів охорони здоров 'я, що базується на застосуванні кластерного аналізу за методом ксередніх. Дана технологія дозволить суттєво вдосконалити процес управління лікувально-профілактичним забезпеченням Збройних Сил України.

2. Визначено, що військові лікувальні заклади за використаними у дослідженні показниками групуються у типові за візуальними характеристиками (графіки середніх) кластери, при цьому розподіл за кластерами здійснюється відповідно до ефективності та повноти використання розгорнутого ліжкового фонду.

3. В деяких лікувальних закладах охорони здоров'я Збройних Сил України (віднесених до кластерів № 4 та № 3) розгорнуті ліжка використовувались недостатньо інтенсивно, що проявилось у зменшенні рекомендованих нормативних значень окремих показників [3]: середнього числа днів зайнятості ліжка за рік ${ }^{1}$ в ВМКЦ Північного регіону, ВМКЦ Кримського регіону, 386 (м. Сімферополь), 1129 (м. Рівне), 1445 (м. Староконстантинів), 498 (м. Луцьк) та 450 (м. Запоріжжя) військових госпіталях до 277,29, 257, 17, 279,81, 231,36, 232,49, 274,00та241,05 днів відповідно; оберту ліжка до 23,18 в середньому для зак- ладів кластера № 4 та 22,54 в середньому для закладів кластера № 3. Середнє число днів перебування хворих на ліжку для перерахованих закладів було, навпаки, порівняно великим - 12,85 та 11,01 днів для кластерів № 4 та № 3 відповідно в порівнянні з 9,17 дня для закладів кластера № 2.

4. Грунтуючись на результатах досліджень, можна рекомендувати використання кластерного аналізу, здійсненого за методом ^^-середніх, для щорічного оцінювання результатів діяльності лікувальних закладів охорони здоров'я Збройних Сил України.

Керівництву закладів охорони здоров'я, віднесених до кластерів № 4 та № 3, та органам управління медичною службою Збройних Сил України рекомендується вжити заходи, спрямовані на підвищення якості оперативного управління ліжковим фондом, а саме: зменшити терміни лікування хворих до мінімально необхідних за рахунок інтенсифікації та підвищення якості лікування; впровадити тимчасове скорочення розгорнутих ліжок у сезони та місяці із зменшеною госпіталізованою захворюваністю (травень, літні місяці, вересень); покращити взаємодію 3 медичною службою військових частин та з'єднань 3 метою безперешкодної госпіталізації хворих із віддалених гарнізонів зони відповідальності; посилити роботу з покращення якості стаціонарної медичної допомоги для попередження звертання хворих із контингентів, що підлягають лікуванню у лікувальних закладах Міністерства оборони України, до закладів інших міністерств та відомств (Міністерства охорони здоров'я України тощо).

Збройних Сил України на 2006-2011 роки / Міністерство оборони України. - К. : ПП "Москалюк В. М.", 2006. - 22 с. 5. Жаховський В. О. Аналіз показників використання ліжкового фонду лікарняних закладів охорони здоров'я Збройних Сил України у 2008-2009 рр.: інформ.-аналіт. матеріали / В. О. Жаховський, Є. Б. Лопін, М. Ю. Антомонов ; ВМД МО України, НДІ ПВМ ЗС України. - К., 2011. - 51 с.

6. Щорічна доповідь про результати діяльності системи охорони здоров'я України. 2008 рік / Український інститут стратегічних досліджень МОЗ України. - К., 2009. - 384 с.

7. Щорічна доповідь про результати діяльності системи охорони здоров'я України. 2009 рік / за ред. 3. М. Митника // Український інститут стратегічних досліджень МОЗ України. - К., 2010. - 602 c.

8. Про затвердження Табеля термінових донесень з медич-

4. Програма розвитку системи медичного забезпечення

\footnotetext{
${ }^{1}$ Показник використання фактичної ліжкової потужності фактично є вираженим у відсотках середнім числом днів зайнятості ліжка за
} рік, але останній показник більш зручний для порівняння з показниками цивільних закладів охорони здоров'я України. 
ної служби (№7) [ Текст] : директива Начальника Генерального штабу Збройних Сил України №2 ДГШ-11 від 17 груд ня 2001 року / Міністерство оборони України. - К., 2001. $473 \mathrm{c}$.

9. Методичний посібник з основних питань організації медичного забезпечення Збройних Сил України / [М. І. Бадюк, В. А. Баркевич, О. Ю. Булах та ін.]. - К.: Департамент охорони здоров'я Міністерства оборони України, 2006. $499 \mathrm{c}$.

10. Антомонов М.Ю. Математическая обработка и анализ медико-биологических данных. - К. : " Фірма Малого Друку", 2006. - 558 с.

11. Антомонов М. Ю. Аналіз методик нормування показників, що використовуються для інтегральної оцінки діяльності закладів охорони здоров'я / М. Ю. Антомонов, С. Б.
Лопін // Гігієна населених місць: Зб. наук. праць. - К. : Полімед, 2008. - Вип. 52. - С. 463-470.

12. Основы математической статистики : Учеб. пособ. для ин-тов физ. культ. / Под ред. В. С. Иванова. - М. : Физкультура и спорт, 1990. - 176 с., ил.

13. Методика визначення інтегральної рейтингової оцінки військових госпіталів Міністерства оборони України / [Антомонов М. Ю., Булах О. Ю., Лопін Є. Б. та ін. ] - К.: НДІ ПВМ ЗС України, 2006. - 24 с.

14. Методика визначення інтегральної рейтингової оцінки військових госпіталів Міністерства оборони України (варіант №2 - переглянутий та доповнений) / [Антомонов М. Ю., Лопін Є. Б., Мостовий В. В. та ін. ] - К. : Департамент охорони здоров'я Міністерства оборони України, 2007. $29 \mathrm{c}$. 